\title{
Comparative Reading as an Interfaith Dialogue: Reincarnation in the Bhagavad Gita and Resurrection in Thomistic Theology
}

\author{
David Muthukumar SIVASUBRAMANIAN \\ South Asia Institute of Advanced Christian Studies, India
}

\begin{abstract}
In a context such as India, religious differences are the focal point of almost every sociopolitical interaction amid growing religious intolerance. This article proposes comparative theology as a viable approach, because it takes religious diversity seriously and accords due respect to other religious texts and practices. But while seeking knowledge that bridges religious boundaries, one may confront the possibility of confronting "logically inassimilable" differences in the form of conflicting truth claims. This article will argue that by using apologetics as a truth-seeking endeavor we can constructively approach such instances of cognitive dissonance. For this purpose, a comparative study of reincarnation from the Bhagavad Gita and the resurrection from Thomistic theology will be used as a case study.
\end{abstract}

\section{Keywords}

comparative theology, interfaith dialogue, Thomism, Bhagavad Gita, reincarnation, resurrection

\section{INTRODUCTION}

Religious diversity is palpable across all sections of human society. Whether it is the rich or the poor, native or alien, male or female, the category of religion often overshadows every other category used to classify human beings. Contrary to the whimsical predictions of the socalled "masters of suspicion," religion has not vanished but has resuscitated 
itself as the one vital aspect that is factored into all or most civil, political, and moral discourses. Thus, religious plurality is an ineluctable force that must be navigated in order to communicate meaningfully across social and cultural borders. Especially in a context such as India, amid the growing religious intolerance toward minorities, religious differences are the focal point of every sociopolitical interaction. Indian Christians, as a religious minority, often find themselves in the crosshairs of such discriminatory discourses and hence need to reflect on the question of their identity and their direct relationship with the majority community.

A quick review at the kind of responses proffered by Christians brings three terms to mind: exclusivism, inclusivism, and pluralism. The Christian exclusivist claim, along with Western cultural hegemony, has been decried in modern postcolonial reflections and is still regarded as one of the critical factors in Indian Christians being perceived as "agents of the West." The inclusivist notion that Christianity fulfills the partial truths of other religions entails a condescending presumption "to know non-Christians better than they know themselves."1 While pluralism rejects the notion that any single tradition, Christianity in particular, has privileged access to divine truth, it avoids the difficulty of religious difference by relativizing those differences. ${ }^{2}$ Thus, it can be inferred that all the past responses of the theology of religions are not taking religious diversity seriously. Also, given the little impact these earlier responses have made in the sphere of religious diversity, and amid the ominous trend of growing religious fundamentalism and bigotry, can a Christian theologian, especially an Indian Christian theologian, attempt differently in order to develop a healing and enduring relationship with the neighboring faiths?

Prominent Indologist and Harvard professor Francis Clooney offers a solution. He says, "If we want to take diversity and religious commitment seriously, then there is a need for comparative theology, a mode of interreligious learning particularly well suited to the times in which we

1 Hugh Nicholson, "The New Comparative Theology and the Problem of Theological Hegemonism," in The New Comparative Theology: Interreligious Insights from the Next Generation, ed. Francis X. Clooney (New York: T\&T Clark, 2010), 44.

2 Hugh Nicholson, Comparative Theology and the Problem of Religious Rivalry (New York: Oxford University Press, 2011), x. 
live." ${ }^{3} \mathrm{He}$ also notes that "as believers, we must also be able to defend the relevance of the faith of our community, deepening our commitments even alongside other faiths that are flourishing nearby." ${ }^{4}$ Clooney advocates being faithful to our home tradition while deeply learning across religious borders. John Thatamanil, an Indian American theologian, also points out that comparative theology will be an appropriate response as "a new stage in Christian theology's encounter with other religions." 5 In order to address Indian religious diversity and devise a viable theological response, this comparative theological mode of engaging other religions seriously could provide a feasible method.

When we enter into another religious tradition in order to study it in comparison with one's own tradition, we may encounter similar notions of piety expressed through its religious texts and practices. But we may also confront "logically inassimilable" differences in the form of conflicting truth claims, as each religion tends to make particular faith claims with a universal scope. For example, we cannot hold the notions of "Brahman only is Real" and "Jesus is the only Way" without suffering cognitive dissonance. I will argue that while we need to learn from the parallels between religious traditions, we must also confront such instances of cognitive dissonances without shying away. However, I will argue that instead of indulging in a polemical war over such conflicting religious conceptions, one needs to learn to use such knowledge of irreconcilable differences to augment one's understanding of one's own tradition while also unlearning the stereotypical presumptions about the other religion.

Toward this purpose, I will begin by discussing the aspects of the comparative theological approach. This will be followed by a constructive proposal for vada-apologia comparison that avoids polemical tendencies and facilitates cross learning among different religious traditions. ${ }^{6}$ Finally, through a serious textual study of the aspect of reincarnation from selected

3 Francis X. Clooney, Comparative Theology: Deep Learning Across Religious Borders (Malden, MA: Wiley-Blackwell, 2010), 3.

4 Clooney, Comparative Theology, 7.

5 John J. Thatamanil, The Immanent Divine: God, Creation and the Human Predicament (Philadelphia, PA: Fortress Press, 2006), 3.

$6 V \bar{a} d a$ is the Sanskrit term for a discourse that aims toward arriving at the truth of the matter. This will be developed further in the latter part of the essay. 
verses of the Bhagavad Gita, a comparative self-reflection will be attempted with the help of Thomas Aquinas's understanding of the resurrection.

\section{Comparative Theology}

Comparative theology, as an interreligious approach, emphasizes the fidelity of a theologian to her own tradition while respectfully venturing into learning from another religion. Clooney defines comparative theology as the "acts of faith seeking understanding which are rooted in a particular faith tradition but which, from that foundation, venture into learning from one or more other faith traditions." theology starts from the Anselmian fides quaerens intellectum (faith seeking understanding) within one's home tradition before approaching other religious traditions for the purpose of cross learning. The American Academy of Religion's Comparative Theology Group develops this notion further:

Comparative (Interreligious) Theology is ... primarily a matter of faith seeking understanding ... and this faith as enacted in meditation, visualization practice, ritual, and ethical behavior. Like other forms of theology, it is about and for the sake of knowledge of God or, more broadly, the ultimate mystery toward which life points. In a theology that is comparative, faith and practice are explored and transformed by attention to the parallel theological dimensions of one or more other religious and theological traditions. ${ }^{8}$

Faith seeking understanding does not confine itself to one's own theological resources but also seeks "parallel theological dimensions." It takes advantage of the opportunities as well as difficulties present in the "encounters between peoples, religions, and cultures that are rife in the postmodern condition." It also aims at better comprehension, "precisely

7 Clooney, Comparative Theology, 10.

8 Tracy Sayuki Tiemeier, "Comparative Theology as a Theology of Liberation," in The New Comparative Theology, 139, citing "Statement for the Comparative Theology Group for the AAR," http://myweb.lmu.edu/ttiemeier/GroupStatement.html (accessed November 5, 2008).

9 A. Bagus Laksana, "Comparative Theology: Between Identity and Alterity," in The New Comparative Theology: Interreligious Insights from the Next Generation, ed. Francis X. Clooney (New York: T\&T Clark, 2010, 3. 
by intensifying this encounter through committed crosslearning." ${ }^{10}$ Comparative theology is thus essentially interreligious, and the intention is to learn by comparing notes, so to say, between religious traditions. "In some instance, this comparison may involve evaluation, but ordinarily, the priority is more simply the dynamics of a back-and-forth learning." 11 Though the evaluation of theological concepts or religious practices is part of this exercise, Clooney wants to go beyond that. He says:

It is, therefore, not primarily a matter of evaluation, as if merely to compare A and B so as to determine the extent of their similarity and which is better... Rather, as a theological and necessarily spiritual practice ... comparison is a reflective and contemplative endeavor by which we see the other in light of our own, and our own in light of the other. ${ }^{12}$

As a comparative theologian retains the confessional character of her reading through the ideal of "faith seeking understanding," it becomes not only an academic exercise but, as Clooney conceives, even a spiritual practice. In his writings, Clooney engages in an intense study of the Hindu texts in Sanskrit and Tamil and reflects on them from a Christian perspective. He often highlights the Christian spiritual dimension of such a task.

James Frederick captures the full scope of comparative theology by saying, "[It] is not only a revisionist but also a constructive project in which theologians interpret the meaning and truth of one tradition by making critical correlations with the classics of another religious tradition." ${ }^{13} \mathrm{He}$ identifies that comparative learnings can be a constructive process in which a theologian can employ interpretative tools to the text of other religions. He describes this process as follows:

The comparison begins with the critical study of another religion, sometimes by means of the reading of classic texts, sometimes by means of personal dialogue with the practitioners of the other religious paths, and

10 Laksana, "Comparative Theology," 3.

11 Clooney, Comparative Theology, 11.

12 Clooney, Comparative Theology, 10-11.

13 James Fredericks, "Introduction," in The New Comparative Theology: Interreligious Insights from the Next Generation, ed. Francis X. Clooney (New York: T\&T Clark, 2010), $x-x i$. 
optimally by taking both routes. The conversation with the other tradition eventually becomes a conversation within the home tradition in which its classic texts, art, rituals, ascetic practices, etc. are reinterpreted in light of the study of the other tradition. ${ }^{14}$

By engaging other religious texts intensely, comparative theology aims at influencing one's previous understanding about a particular concept or practice of another religion as well as one's own. It is a theological discipline that seeks fresh understanding outside one's home tradition while remaining faithful to it. ${ }^{15}$ Clooney also avers that through this comparative exercise, "we unlearn our prejudices and learn the truth of other religious claims." ${ }^{16}$ Thus, "Finally, we see ourselves differently, intuitively uncovering dimensions of ourselves that would not otherwise, by a non-comparative logic, come to the fore." ${ }^{\prime 17}$ Instead of presupposing another religious truth about a particular doctrine or concept, a comparative theologian undertakes a serious study of the religious text in question and then reflects back into one's own faith tradition. A comparative theologian, therefore, has a particular responsibility to all the traditions considered. While she accepts the responsibility of representing her own religious tradition faithfully, she also must represent the other religion in a trustworthy manner. ${ }^{18}$ Clooney affirms this, saying, "[it is a] commitment to a religious community, respect for its scriptures, traditions, and practices, and a willingness to affirm the truths and values of that tradition." ${ }^{19}$

\section{Apologetics as Truth-Seeking}

Following the confessional character of the comparative theology exercise, both Clooney and Fredericks also affirm the apologetic dimension as its attendant feature. Frederick argues for robust apologetics to be part

14 Fredericks, "Introduction," xi.

15 Clooney, Comparative Theology, 11.

16 Clooney, Comparative Theology, 11.

17 Clooney, Comparative Theology, 11.

18 Tracy Sayuki Tiemeier, "Comparative Theology as a Theology of Liberation," in The New Comparative Theology: Interreligious Insights from the Next Generation, ed. Francis X. Clooney (New York: T\&T Clark, 2010), 141.

Clooney, Comparative Theology, 11. 
of comparative learning. ${ }^{20} \mathrm{He}$ is also quick to note, "A proper apologetics, however, does not render certain theological affirmations immune from the need to be revised by means of comparison with the affirmations of another tradition. ${ }^{21}$ Nicholson notes that the kind of apologetics Clooney and Frederick propose is similar to what the "Indian logicians would have called vada, a debate motivated by a quest for truth, as opposed to jalpa, one motivated by a desire for victory." ${ }^{22}$ However, he also points out that, as history shows, even such debates that were intended as "quests for truth [could] also degenerate into impassioned polemics." ${ }^{\text {23 }}$ However, for him, the benefit of such an apologetical initiative is "its ability to highlight and clarify the substantive theological differences that exist between different theological traditions." ${ }^{24}$ Also, he suspects that unchecked apologetics may induce theological hegemonism and devolve into illiberal polemics. ${ }^{25}$ Nicholson observes that comparative theology then might require "a patient willingness to live with the inevitable tensions, ambiguities, and uncertainties of religious life." 26

Nicholson further observes that "comparative theological method comes down to a balancing act between openness and commitment ... by which I mean the binding together of two logically irreconcilable claims in a necessary relation. ${ }^{.27}$ Clooney and Frederick thus rely on the openness and commitment of the comparative method to avoid polemical tendencies. When a comparative theologian reflects back into her own theological tradition, the contrasting theological significance of the other religious concept or practice can bring more illumination to her understanding. That is the kind of apologia that will be true to the vada of seeking truth and not the jalpa of desiring victory by denigrating the other religion. This "vada-apologia" model of comparative theology, which incorporates cross

20 Fredericks, "Introduction," xii.

21 Fredericks, "Introduction," xii.

22 Nicholson, "The New Comparative Theology," 46.

23 Nicholson, "The New Comparative Theology," 46.

24 Nicholson, "The New Comparative Theology," 61.

25 Nicholson, "The New Comparative Theology," 45.

26 Nicholson, "The New Comparative Theology," 45.

27 Nicholson, "The New Comparative Theology," 64. 
learning across religious traditions, also aids in a reasonable presentation of one's faith.

In such a process of cross learning across traditions, a theologian will not engage in judging the truth or falsity of another religious claim but will responsibly learn. Upon returning to theologizing in one's own context, the differences will not be blurred or refuted, but in the contrast of such conflicting positions, the theologian will seek to appreciate her own tradition and articulate it clearly with conviction. This model of comparison will help in "the need to understand the Other in a way that does not annul the Other's alterity." ${ }^{28}$ Applying the principles of such a "vada-apologia" model of comparative reading, a Hindu text will be studied and reflected upon from a Christian perspective.

\section{COMPARING REINCARNATION AND RESURRECTION}

For our purpose of the comparative exercise, the Bhagavad Gita text on reincarnation is chosen. Again, the reason for selecting this text is subjective and is chosen in order to explore the understanding of the meaning of life and death as a reincarnation cycle in contrast to the Christian notion of one life, one death, and resurrection. The vada-apologia comparative reading will aim to overcome the original polemical intentions through a serious study of the Hindu text at its face value.

\section{Reading the Bhagavad Gita}

The Bhagavad Gita, the "Song of the Lord," is a Sanskrit poem composed in seven hundred numbered stanzas, divided into eighteen chapters, in the form of a dialogue between Krishna, a god in human form, and Arjuna, a heroic warrior. Their discourse takes place on the eve of a cataclysmic battle on a field between two armies of warring cousins. Arjuna, realizing that if he fights, he will be forced to kill his friends, relatives, and teachers, casts down his bow and arrow (he is a great archer), and refuses to engage in combat. The Gita unfolds as a discussion of Arjuna's moral dilemma, with Krishna as the wise interlocutor explaining to Arjuna that he must overcome his instinctual revulsion and must attend to his duties as a

28 Fredericks, "Introduction," xiii. 
warrior. Krishna also eventually reveals himself as an incarnation of God in human form..$^{29}$

This text is located in the second chapter, titled Sānkhya Yoga. In this passage, Krishna discusses Sānkhya philosophy, which is based on the right knowledge of the Supreme Consciousness, Brahman. The meaning of the word Sānkhya is "correct knowledge" and finds correspondence with the Vedanta, which systematically explains the correct knowledge and presence of Consciousness. We will study verses 22, 23, 24, 26, and 27.

\section{Verse\#2.22}

vāsānsi jīrnāni yathā vihāya navāni gruhnāti naroparāni tathā śarīrāni vihāya jīrnānyanyānni sanyāti navāni dehī

\section{Translation}

Someone who has abandoned worn-out garments sets out to clothe himself in brand new raiment; just so, when it has cast off worn-out bodies, the embodied one will encounter others. ${ }^{30}$

Analysis

Krishna is telling Arjuna that the death and life process is as simple as changing clothes. Adi Sankara comments on this verse: "Just as, in this world, a man casts off the clothes that have been worn-out and puts on others which are new, in the same manner, like the man (of the world), the embodied Self abandons old bodies, and, without undergoing any change, enters others which are new." 31 The soul does not undergo any change in the process of life and death, but merely sheds the old body and seeks and finds new bodies at the new birth. Krishna's intention in telling this to Arjuna is to help him to understand that death is not a permanent cessation but only an event in the continuing samsara - the cycle of death and rebirth to which life in the material world is bound.

29 This introduction is taken from The Bhagavad Gita: Norton Critical Editions (W. W. Norton \& Company, 2016), 1.

30 Gavin Flood, ed., The Bhagavad Gita, trans. Charles Martin (New York: W. W. Norton \& Company, 2014), 66.

31 Alladi Mahadeva Sastry, trans., The Bhagavad-Gita: With the Commentary of Sri Sankaracharya; Translated from the Original Sanskrit into English (Chennai: Samata Books, 1981), 35. 
Verse\#2.23-24

nainam chindanti śastrāni nainam dahati pāvakah

na chainam kledayantyāpo na śoshayati mārutah

acchedyoyamadāhyoyamakledyo aśoshya eva cha

nityah sarvagatah sthānurachalo ayam sanātanah

Translation

Weapons do not cut it. Fire does not burn it. Water cannot make it wet, and air cannot dry it. It can never be cut, never be burned, can never be wetted, nor be dried up; it is changeless, omnipresent, fixed, unmoving, and it exists but has no external cause for its existence. ${ }^{32}$

Analysis

No weapon can cut the Consciousness because it is not material, and it has no limbs that can be cut by weapons. The process of cutting, burning, wetting, and drying is possible with matter because weapons, water, fire, and wind all are material energies. Unlike the material body, the immaterial soul does not undergo any change, nor can any change be imputed to it. It is, therefore, everlasting, all-pervading, and not caused by any new cause. Sankara comments, "Because the mutually destructive objects - namely, swords and the like-cannot destroy the Self; therefore $\mathrm{He}(\mathrm{sic})$ is everlasting. Because everlasting, $\mathrm{He}$ is all-pervading. Because of all-pervading, He is stable like a pillar. Because stable, the Self is firm. Wherefore He is eternal, not produced out of any cause, not new."33

The individual Consciousness or soul is the manifestation of the Supreme Consciousness in an individual. The $M \bar{a} y \bar{a}$, the veil of ignorance, conceals the truth of Self's own Supreme existence, and thus it is caught up in the experience of the world of duality. As desires arise in individual Consciousness after experiencing the $M \bar{a} y \bar{a}$, the individual Consciousness is caught in the cycle of forceful births and deaths. For the Self to be

32 Swami Saurabhnath, Bhagavad Gita-Pure: A Comprehensive Study without Sectarian Contamination, 67, https://www.amazon.com/Bhagavad-Gita-ComprehensiveSectarian-Contamination-ebook/dp / B018MQDZL4/ref=sr_1_1?s=books\&ie=UT F8\&qid $=1515692663 \&$ sr $=1-1 \&$ keywords $=$ Swami + Saurabhnath $\% 2 C+$ Bhagavad $+\mathrm{G}$ ita (accessed December12, 2017).

33 Sastry, The Bhagavad-Gita, 36. 
reconnected to the Supreme Consciousness, this veil of ignorance has to be removed. But the Self, despite the transient influence of Māyā will always be free from all influences of material energies. Here Krishna is emphasizing the immateriality of the soul and its eternal nature, which cannot be corrupted.

\section{Verse\#2.26-27}

atha chainam nityajātam nityam $v \bar{a}$ manyase mrutam tathāpi tvam mahābāho nainam śochitumarhasi

jātasya hi dhruvo mrutyurdhruvam janma mrutasya cha tasmādaparihārye arthe na tvam śochitumarhasi

\section{Translation}

Even if you think of it as being born and dying unendingly, in that case also, O Arjuna, you should not grieve for this. For death is certain to anyone who is born, and birth is certain for the dead. Therefore, you should not grieve for something unavoidable. ${ }^{34}$

\section{Analysis}

Sankara comments on these verses:

... to that which is born, death is indeed certain; and to that which is dead, birth is certain. Therefore, about the unavoidable thing, thou ought not to grieve. To that which has had birth, death happens without failure, and birth is sure to happen to that which is dead. Since birth and death are unavoidable, therefore you ought not to grieve regarding such an unavoidable thing. If death is natural to that which has had birth, and if birth is natural to that which has had death, the thing is unavoidable. Regarding such an unavoidable thing, you ought not to grieve. ${ }^{35}$

Krishna says that death and life is a cycle that continues for eternity, and hence Arjuna should not be grieving for anybody's death, because it is inevitable that after birth, death will follow, and those who are dead are

34 Swami Saurabhnath, Bhagavad Gita, 69.

35 Sastry, The Bhagavad-Gita, 37. 
going to be born again. What is essential is for Arjuna to do his duty (dharma) without fail.

These few verses address the pivotal point in the narrative of the Bhagavad Gita. Arjuna, as a warrior, hesitates to fulfill his duty (dharma) as he was weighing the psychological pain of losing his people against whom he is fighting. Using this context, Krishna is instructing Arjuna about the eternal and imperishable nature of the human soul and the transient nature of the body. The Hindu ethic of dharma over everything defines the plot. As a warrior, Arjuna is obligated to fight the battle, and his misunderstanding about the meaning of human life stands in the way of fulfilling it. Krishna helps him to understand that the soul of a human being is one with the Supreme Consciousness and hence is indestructible. Therefore, even if he has to kill his cousins in the war, he is not permanently destroying their soul, but only the temporary body.

Moreover, the soul that is caught in the samsara cycle will seek a new body after death as one leaves old clothes and puts on new ones. As Sankara and other commentators explain, the Vedantic concept of Aham Brahmasmi (I am Brahman) Tat Tvam Asi (That Thou Art) are the underlying principles of Krishna's teaching. ${ }^{36}$ Every individual is an instance of the very manifestation of the Eternal Reality. However, since having been caught up in the karma-samsara cycle, the superimposition of unreal for the Real prevents humans from self-realizing this most significant reality. However, the Soul or Consciousness is incorruptible and will eventually attain its union with the Brahman. Thus the Hindu anthropology advocates a cyclical, multiple life-death sequence before transcending the material world.

\section{Comparative Reflection with Aquinas}

Through the study of these few verses from the Bhagavad Gita, one thing that stands out is the emphasis on the stark dualism of the bodysoul composition. It repeatedly emphasizes the immateriality of the soul and the materiality of the body. However, such dualistic conceptions are also native to the biblical understanding, especially in the New Testament writings, where substance dualism is present as a prevalent notion. Jürgen

36 J. G. Suthren Hirst, Samkara's Advaita Vedanta: A Way of Teaching (London: Routledge, 2005), 81 . 
Moltmann observes that "from its earliest beginnings, the history of Western anthropology shows a tendency to make the soul paramount over the body, which is thus something from which the person can detach himself, something to be disciplined, and made the instrument of the soul." ${ }^{37}$ The use of the Greek philosophical framework with its attendant notion of dualism can be traced both in the New Testament texts as well as in the early church expositions. The church fathers were dualists in their understanding. Tertullian wrote, "Without the soul, we are nothing." ${ }^{38}$ Augustine thought that the human soul, and especially its rational part, is superior to the body. ${ }^{39}$ Hence, the dualistic understanding of the Bhagavad Gita can be understood as having similarities within the Christian conception.

Also, this dualistic understanding of the Bible is often balanced by a holistic understanding of the Old Testament. Nephesh, a term in the Hebrew Bible, has a wide variety of meanings: "soul," "mind," "person," "body," as well as "life," which refers to the holistic view of a human being. ${ }^{40}$ There are not different vocabularies in Hebrew to denote the composition of an individual. Nephesh signifies human life in its entire existence. ${ }^{41}$ Biblical scholars often appeal to this holistic notion of Hebrew understanding as an antidote to the dualistic notion in the NT.

Coming back to the Bhagavad Gita, what is surprising is that, while we see a rigid dualism in the Bhagavad Gita as even Sankara comments on it, we also understand that his Vedanta advocates a monism or, to be specific, "nondualism." On closer scrutiny, we can realize that, in the larger scheme of things, this overarching monism serves as the antidote for substance dualism. Sankara posited that only Brahman is Real, and everything else is a mere manifestation. Therefore, it is possible to understand the apparent

37 Jürgen Moltmann, God in Creation: A New Theology of Creation and the Spirit of God (San Francisco, CA: HarperSanFrancisco, 1985), 245.

38 Tertullian, The Sacred Writings of Tertullian, vol. 2 (Loschberg, Germany: Jazzybee Verlag, n.d.), 71.

39 Augustine, On the Trinity, Book XV 15:7:11, 2017, http://www.newadvent.org/ fathers/130115.htm (accessed December 8, 2019).

40 Stephen D. Renn, Expository Dictionary of Bible Words: Word Studies for Key English Bible Words Based on the Hebrew and Greek Texts (Peabody, MA: Hendrickson Publishers, 2005), 594.

41 Renn, Expository Dictionary, 594. 
body-soul dualism as being balanced out within the nondual conception of Brahman. ${ }^{42}$ I think this corresponds to the method that Christian theologians are employing to overcome the dualistic constructions in the Bible that we observed earlier. While comparing the possible parallels in this manner, one also needs to be aware of the multiple strands of understanding about Reality within Hinduism (Dvaita, Vishistadvaita, and so forth). But instead of accentuating the differences and claiming a supreme value for Christian theologizing, it behooves us to understand the fluidity of conceptions on both sides.

However, we need to be aware of the fact that there is also an element of "untranslatability" and "incommensurability" (George Lindbeck's concepts) between the religious traditions. ${ }^{43}$ These are the moments when one suffers cognitive dissonances by attempting to balance these conflictual conceptions. One such moment that we encounter in this passage is when the Christian theologian tries to comprehend the meaning of life and death as reincarnation. This is vastly different from the Christian understanding of one life, one death, and the final resurrection. ${ }^{44}$ How does one respond to this situation as a Christian? It has to be believed that the answer is not simple. However, the possibility that the concept of reincarnation giving a contrasting perspective and enhancing one's understanding of the resurrection is always present. There is definitely an element of evaluation involved in this, but not in judging the merits of one against the other.

Let us consult Thomas Aquinas's expositions on the resurrection, within the Christian (home) tradition, in order to review and present an apologia (a reasonable presentation) of the resurrection in the light of our recent study on reincarnation. Aquinas, like Adi Sankara, also posits that the rational soul is an incorruptible substance while the body is mortal and corruptible. Aquinas says, "It is necessary to say that the principle of intellectual operation, which we call the soul of a human being, is a nonbodily and subsistent principle." ${ }^{45} \mathrm{He}$ also differentiates between the

42 Hirst, Samkara's Advaita Vedanta, 55.

43 Cf. George A. Lindbeck, The Nature of Doctrine: Religion and Theology in a Postliberal Age (Philadelphia: Westminster John Knox Press, 1984).

44 Hebrew 9.27 says, "Just as people are destined to die once, and after that to face judgment" (NIV), signifying that the one life and one death phenomenon is the norm for humanity.

45 Summa Theologiae, 1a, Q. 75, Art. 2. 
soul and the body as he assigns priority to the intellectual faculty to the soul. He says, "The intellect, according to its nature, is elevated altogether above matter, which its activity shows: we do not understand anything unless we separate it from matter." ${ }^{36}$ This material-immaterial conception of soul-body is significant in his conception, which also corresponds to the Bhagavad Gita's view. Aquinas further contends that the soul does not need the body for its activity but only provides it with an object, which is the essence of all material things. ${ }^{47} \mathrm{He}$ contends that even though thinking is attended by bodily activities such as sense perception or imagination, thinking itself is not a bodily activity. ${ }^{48}$ Aquinas's view is apparently not consistent with the modern cognitive neuroscientific studies that emphasize the embodied and embedded nature of human conception. He associates the faculty of thinking with the soul, and hence the body is assigned only a secondary role for its functioning through sensory perception.

However, Aquinas denies the dualistic, platonic conception that a human being is soul only and the body-soul union is unnatural, as it was argued that bodily affections and desires obscure our thinking. He identifies the soul, the incorruptible substance, as the form of the body, and thus its need for the body (matter) for its perfection. ${ }^{49} \mathrm{He}$ would argue that in as much as the soul is the form of the body, it does not have an existence apart from the body; Through its existence, it is immediately united with the body. ${ }^{50}$ Aquinas differs significantly from the Bhagavad Gita's conception of the impermanence of the unity of the body and the soul as the unity will be broken at the point of death, and the soul was conceived to assume a new body at each instance of its birth. For Aquinas, the soul is "created" to be the soul of a particular human being, and thus to be part of the unity that constitutes a person and will always retain the relation to a particular body. ${ }^{51}$ Aquinas asserts, "Now if someone wants to say that the intellective soul is not the form of the body, then it is incumbent on that person to find a way in which the action that is thinking is the action of a

\footnotetext{
46 ST, 1a, Q. 75, Art. 2.

47 ST, 1a, Q. 75, Art. 2.

48 ST, 1a, Q. 12, Art. 4.

49 ST, 1a, Q. 75, Art. 2.

50 ST, 1a, Q. 76, Art. 7.

51 ST, 1a, Q. 75, Art. 4.
} 
particular human being. For each one of us experiences that it is oneself who thinks." 52 It is the subject who thinks and senses and not her soul in one case and her body in another. He establishes that the speaker-the self-is the real existing unity of which the soul and the body are parts. ${ }^{53}$ As per Aquinas's understanding, while the soul has a functional priority, nevertheless, it depends on the body for its existence and also continuity.

This continuity between the soul and body is extended to the afterdeath existence. Aquinas understands death as being caused by the nature of the soul as imperfect and hence, sinful. He explicates that the ideal of the absolute domination of the rational soul over matter is being forfeited by the soul and thus incurring sin. Of course, this malady of original sin can only be negated by the grace of God in Christ. Everyone dies as the body undergoes the corruption of sin and thus experiences the destruction of the body. However, the intellect is not destroyed because its immateriality ensures its incorruptibility. And Aquinas envisions that death is an unnatural event for the nature of the rational soul as the form is to be united with the body, its matter. ${ }^{54} \mathrm{He}$ clarifies:

If therefore, we consider the nature of the soul, then death is unnatural. However, if we consider the nature of the soul and the disposition which on account of the soul was supernaturally given to the human body from the beginning, it is per accidens and against nature, since to be united with the body is natural for the soul..$^{55}$

Aquinas builds up his argument by stating that this unnatural separation will be reconciled through the resurrection of the composite unity of the body and the soul. When the relation between the soul and the body is broken at death, even then, the soul retains the desire for the reunion with its body. According to him, such a natural desire is not in vain, and therefore

52 ST, 1a, Q. 76, Art. 1.

53 ST, 1a, Q. 76, Art. 1. Aquinas considers both Plato's and Aristotle's understandings as unsustainable as they fail to understand this essential unity of the person, comprised of both the soul and the body. Plato says that the human being is the soul, but he fails to account for why the soul is bound up with the body. Aristotle, while confirming the unity of the body and soul, still envisages that reason is our temporary visitor and fails to answer why it is oneself who understands and wills.

54 Contra Gentiles, IV, Q. 81, art. 1-3.

$55 C T, 152$. 
the reunion of the soul and the body will eventually be realized in the resurrection of the body. ${ }^{56} \mathrm{He}$ identifies the active cause of resurrection as a cause beyond nature that is God, who is also the very cause of nature. He says of resurrection: "...but its active principle is not natural, but it is caused solely by divine power." ${ }^{\text {" }}$

Aquinas thus proposes the doctrine of the resurrection of the body as the most reasonable reality among any other alternatives. ${ }^{58} \mathrm{He}$ claims, "If the resurrection of the body is denied, it is not easy but difficult to uphold the immortality of the soul." ${ }^{.9}$ For him, the human being is both rational and material, and to deny this is to deny the truth. As he has already established that the rational soul is immortal and the form of the human being; for us to be is to be immortal and embodied. ${ }^{60}$ For Aquinas, the possibility of a reincarnation that does not affirm the unity of the body and soul is less feasible than the possibility of a resurrection.

This view that upholds the unity of the body and the soul becomes untranslatable and incomprehensible because of the incommensurability of the text when it is juxtaposed with the view of the Bhagavad Gita. ${ }^{61}$ For Adi Sankara, the idea of an essential unity between the immortal soul and a material body is an untenable position. However, the vada-apologia comparative reading enables one to hold them in tension and learn from each view. As the postmortem reality is speculated within each religious tradition, these individual views make sense to the believers belonging to either tradition. Despite the contrasting nature of these religious worldviews, for a person who stands within either of the faith circles, either the reincarnation or the resurrection makes perfect sense in terms of grasping the postmortem reality. Also, this study, which highlights the contradistinction between the resurrection and the reincarnation, helps to appreciate one's Christian hope for the resurrection of the body (which will be restored in its unity with the soul, in its integrity as a person).

\footnotetext{
56 ST, 1a, Q. 76, Art.1.

57 CG, IV, Q. 81, art.14.

58 CG, IV, Q. 81, art.14.

59 I ad Corinthios 15 L. 2

60 CG, IV, Q. 81, art. 14.

61 The incommensurability, as envisioned by Lindbeck, across religions engenders incomprehensibility of theological meaning.
} 
However, all this must be done without passing judgment on the merits of the other tradition as comparative theology concedes the lack of such adjudicating criteria in either tradition.

\section{Conclusion}

The reality of religious diversity is pervasive in today's world, and it has to be navigated carefully in order to counter growing religious fundamentalism and intolerance. However, that requires sensible dialogue across multiple religious communities. The stereotypes and prejudices against particular communities that arise from ignorance of those traditions are deleterious. In a context like that of India, the growing suspicion between the majority Hindu community and the minorities such as Islam and Christianity is damaging the social fabric of the country. Interreligious dialogue should enable cross learnings between traditions that will help unlearn prejudices.

Following Clooney's lead to reading other religious Scriptures respectfully and intensely, the comparative theological method was considered for interreligious dialogue. A preliminary evaluation of the traditional theology of religions' responses was found not to take religious diversity seriously. Clooney and Frederick's definition of comparative theology as primarily a faith-seeking-understanding act that ventures into other religious traditions to learn while being faithful to one's own tradition was found to be promising for such an interreligious endeavor. By not being confined to one's own theological resources, comparative theology encourages one to gain resources outside of one's tradition. Comparative theology is essentially theological in its outlook and its function within the intended interreligious dialogue. Clooney also brought out the spiritual element of comparative learning that is inherent within its academic pursuit. The responsibility of a comparative theologian to affirm her commitment to respect other religious Scriptures, traditions, practices, and faith affirmations is mandated within this method.

We evaluated the apologetic dimensions of the comparative theology and, as Clooney and Frederick conceived, in terms of truth-seeking exercise, it helps one to eschew the polemical tendencies while aspiring for cross learnings across religious traditions. The vada-apologia model of comparative reading overcomes these limitations through its renewed 
focus on learning and unlearning dimensions. According to this, while comparative theology was employed to help a theologian to take another religious tradition-text, ritual practice--seriously, the awareness of irreconcilable differences between religious traditions is also emphasized. This awareness was proposed to overcome the natural polemical tendencies while using the same awareness of differences to enhance one's own faith convictions.

A reading of the Bhagavad Gita verses on reincarnation with the help of native commentaries was attempted. Without passing judgment on the truth or falsity of the content, the significance of that worldview for its believers was construed. Armed with such learning, a self-reflection on the Christian notion of life, death, and resurrection through Thomistic theology brought out the similarities and the "irreconcilable" differences. We were also able to acknowledge the fluidity of conceptions on both sides, which were primarily reflections of the linguistic limits of all religious expressions. The awareness of the unassimilable differences within the concepts of reincarnation and resurrection and hence their incomprehensibility and untranslatability were also acknowledged. In the contrasting light of the other tradition's claims, we learned that we could appreciate our own faith and its significance to us. All this could be done without passing judgments on other religious traditions while earnestly learning from them.

While this method does not claim to have resolved the unresolvable issue of religious conflicts, it does reinforce the notion that by staying true to the confessional character of one's faith, it is possible to seek the truth across religious boundaries and learn mutually.

\section{About author}

David Muthukumar SIVASUBRAMANIAN (PhD, Fuller Theological Seminary) is Associate Professor of Theology at South Asia Institute of Advanced Christian Studies, Bangalore, India. 